\title{
KNEE INJURIES PREVALENCE IN BRAZILIAN JIU-JITSU: EPIDEMIOLOGICAL STUDY
}

\section{PREVALÊNCIA DE LESÕES DO JOELHO NO JIU-JITSU BRASILEIRO: ESTUDO EPIDEMIOLÓGICO}

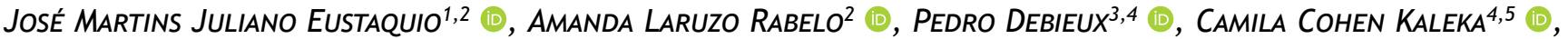 \\ OCTÁVIO BARBOSA NETO ${ }^{1}$ (1)
}

\author{
1. Federal University of Triângulo Mineiro, Research Group on Human Performance and Sport, Graduate Program in Physical Education, Uberaba, MG, Brazil. \\ 2. University of Uberaba, Mário Palmério Hospital, Uberaba, MG, Brazil. \\ 3. Federal University of São Paulo, Knee Surgery and Arthroscopy Group, São Paulo, SP, Brazil. \\ 4. Albert Einstein Israelite Hospital, São Paulo, SP, Brazil. \\ 5. Cohen Institute of Orthopedics, Sports Medicine and Rehabilitation, São Paulo, SP, Brazil.
}

\section{ABSTRACT}

Objective: To evaluate the epidemiological and clinical characteristics of knee injuries in Brazilian Jiu-Jitsu (BJJ) practitioners. Methods: Cross-sectional study, using a mixed questionnaire, based on the Referred Morbidity Index. Results: 198 amateur and professional BJJ fighters, of both sexes, aged between 18 and 60 years, participated in the study. The majority $(88 \%)$ of the fighters had only one knee injury $(p<0.001)$. In total, $29.8 \%$ proportion of knee injuries ( $p<0.001$ ) was identified, which were mainly from the medial collateral ligament (38\%), caused by a sprain mechanism (86\%) and conservative treatment (65\%). Conclusion: A high prevalence of knee injuries in JJB fighters was found, compared to other sports that also perform rotational movements and have great body contact, such as mixed martial arts (MMA), judo, soccer, basketball and handball. Some JJB strikes, such as the key and the projection, can cause greater knee joint stress, both in the attacking fighter and in the opponent. The knowledge of the epidemiological characteristics of sports injuries is important in the elaboration of prevention and training protocols more specific to the sport and for the understanding of the complex mechanisms involved with this outcome in sport. Level of Evidence IV, Case Series.

Keywords: Martial Arts. Knee. Injuries to Athletes. Knee Injuries.

\section{RESUMO}

Objetivo: Avaliar as características epidemiológicas e clínicas das lesões no joelho de praticantes de jiu-jitsu brasileiro (JJB). Métodos: Estudo de desenho transversal, por meio de questionário do tipo misto, baseado no Índice de Morbidade Referida. Resultados: Participaram 198 lutadores amadores e profissionais de JJB, de ambos os sexos, com idades entre 18 e 60 anos. A grande maioria (88\%) dos lutadores apresentou apenas uma lesão no joelho ( $p<0,001)$. Observou-se proporção de 29,8\% de lesões no joelho ( $p<0,001)$, que foram principalmente do ligamento colateral medial (38\%), causadas por mecanismo de entorse (86\%) e de tratamento conservador (65\%). Conclusões: Observou-se alta prevalência de lesões no joelho em lutadores de JJB, comparativamente a outros esportes que também realizam movimentos rotacionais e têm grande contato corporal, como as artes marciais mistas (MMA), o judô, o futebol, o basquetebol e o handebol. Alguns golpes do JJB, como a chave e a projeção, podem causar maior estresse articular no joelho, tanto no lutador que ataca quanto no oponente. O conhecimento das características epidemiológicas das lesões esportivas é importante na elaboração de protocolos de prevenção e treinamento mais específicos à modalidade e também para a compreensão dos mecanismos complexos envolvidos com esse desfecho no esporte. Nível de Evidência IV, Série de Casos.

Descritores: Artes Marciais. Joelho. Traumatismos em Atletas. Traumatismos do Joelho.

Citation: Eustaquio JMJ, Rabelo AL, Debieux P, Kaleka CC, Barbosa Neto O. Knee injuries prevalence in Brazilian jiu-jitsu: epidemiological study. Acta Ortop Bras. [online]. 2021;29(6):327-330. Available from URL: http://www.scielo.br/aob.

\section{INTRODUCTION}

Jiu-Jitsu is a martial art that has undergone an important development process since it started in Brazil, just over a century ago, which culminated in the emergence of Brazilian Jiu-Jitsu (BJJ)..$^{1}$ These modifications were mainly based on stimulating of ground fighting through submission strategies characteristic of this modality.

In BJJ combat, athletes perform intermittent efforts and complex body movements, such as arm lock (Figure 1a) and projection (Figure 1b). ${ }^{2}$ During the execution of these maneuvers, greater

All authors declare no potential conflict of interest related to this article.

The study was conducted at Federal University of Triângulo Mineiro, Research Group on Human Performance and Sport.

Correspondence: Octávio Barbosa Neto. Federal University of Triângulo Mineiro, Research Group on Human Performance and Sport, Graduate Program in Physical Education. Av. Tutunas, 490, Uberaba, MG, Brazil, 38061500. octavio.neto@uftm.edu.br 
joint stress can occur in the different axes of movement, especially in the knees, and this may be one of the triggering factors in the appearance of injuries.

Therefore, BJJ practitioner needs specific physical aptitudes ${ }^{3,4}$ and biomechanical components suitable for their joint homeostasis. ${ }^{5}$ These requirements are also present in other sports, especially those involving rotational movements and great body contact, such as soccer, handball and basketball. ${ }^{6-8}$

Studies have shown that sports injuries occur due to factors that interact through complex biological systems. ${ }^{9}$ Initially, to understand these interactions, studying the epidemiological factors involved in sports injuries is essential. Through this, it is possible to understand the interactions between these factors and, consequently, the adoption of more specific protocols for the prevention of injuries in the sports field.

This study aimed to evaluate the epidemiological and clinical characteristics of knee injuries in BJJ fighters and to compare these segment injuries in other sports.
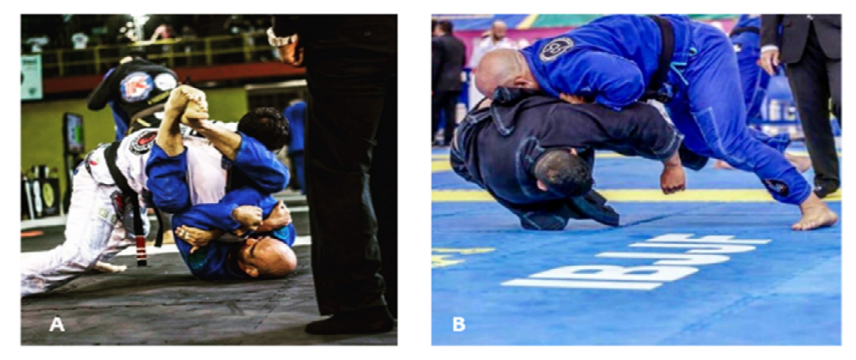

Figure 1: BJJ strikes, known as arm lock (A) and projection (B).

\section{MATERIAL AND METHODS}

This is a Cross-sectional study approved by the Research Ethics Committee of the Federal University of Triângulo Mineiro (n 3636261/2019; CAAE 22824619.1.0000.5154). In the period from December 2019 to March 2020, 217 professional athletes and amateurs practicing BJJ answered a mixed questionnaire, based on the concepts of the Referred Morbidity Instrument. ${ }^{10}$ All participants signed an informed consent form.

The study included participants of both sexes, aged 18 to 60 years, who have been practicing BJJ for at least six months and linked to academies registered at the Brazilian Confederation of Jiu-Jitsu. The exclusion criterion was filling out the questionnaire incorrectly or incomprehensibly.

Musculoskeletal injury was considered as any loss or traumatic event that results from a JJB training or competition and causes total removal from training or other external routines for more than one week, changes from normal training activities in volume or intensity for more than two weeks, and/or any physical complaint severe enough for seeking medical attention to diagnose or treat an injury. ${ }^{11}$ No upper limit on the number of injuries reported by the fighter was imposed. The period of three years prior to the study was used to analyze the injuries presented by the participants.

The injuries reported in the knee segment were divided according to the fighter's epidemiological characteristics, the mechanism of trauma, the types of injuries, the degree of severity and the treatment performed.

\section{Statistical analysis}

Data were processed using Excel ${ }^{\circledR}$ and SigmaStat ${ }^{\circledR} 2.0$ (GraphPad Software Jandel, SPSS, Chicago, IL, USA). The data were reported using descriptive and analytical statistics. For the analysis of qualitative bivariate or multivariate variables, the chisquare test was used, and for the equality test of two proportions, univariate qualitative variables was used. Values of $p<0.05$ were considered significant.

\section{RESULTS}

In total, 198 fighters participated in the study (9\% exclusion rate). Among the participants, 50 (25\%) had some knee injury; the most $(88 \%)$ had only one injury. The prevalence of knee injuries in training was 0.26 injuries per hours of BJJ workout / athlete / year (Table 1).

Table 1. General characteristics of injuries among the JJB fighters participating in the study.

\begin{tabular}{c|c|c|c}
\hline & & $\mathbf{n} / \%$ & $\mathbf{p}$-value \\
\hline \multirow{2}{*}{ Injured JJB fighters } & Yes & $105 / 53 \%$ & 0.23 \\
& No & $93 / 47 \%$ & $0.84 \%$ \\
\hline \multirow{2}{*}{ JJB fighters with } & 1 injury & $44 / 88 \%$ & Ref. \\
knee injuries & 2 injuries & $5 / 10 \%$ & $<0,001$ \\
& $\geq 3$ injuries & $1 / 2 \%$ & $<0,001$ \\
\hline Prevalence of knee & Training hours/year & 63.128 hours & \\
injuries (1.000 & Total knee injuries in training & 49 & - \\
training hours/ & Prevalence (1.000 training & 0.26 & \\
athlete/year) & hours/athlete/year) & & \\
\hline \multicolumn{4}{|l}{}
\end{tabular}

No significant differences in knee injuries were found regarding some characteristics of the fighter, such as sex, age, graduation level, training floor, injury moment, practice of another sport, BJJ training time, BJJ weekly workout and acting as BJJ teacher. The absence time due to these injuries was over four weeks $(p<0.001)$ (Table 2)

Table 2. Qualitative characteristics of knee injuries in JJB fighters.

\begin{tabular}{|c|c|c|c|c|}
\hline & & $\begin{array}{c}\text { Knee } \\
\text { injuries } \\
(\mathrm{n} / \%)\end{array}$ & $\begin{array}{l}\text { Total injuries } \\
(\mathbf{n} / \%)\end{array}$ & p-value \\
\hline Sex & $\begin{array}{l}\text { Male } \\
\text { Female }\end{array}$ & $\begin{array}{c}54 / 95 \% \\
3 / 5 \%\end{array}$ & $\begin{array}{c}177 / 93 \% \\
14 / 7 \%\end{array}$ & 0.5 \\
\hline Age group (years) & $\begin{array}{l}18-29 \\
\geq 30 \\
\end{array}$ & $\begin{array}{l}18 / 32 \% \\
39 / 68 \% \\
\end{array}$ & $\begin{array}{r}52 / 27 \% \\
139 / 73 \% \\
\end{array}$ & 0.37 \\
\hline Tracks & $\begin{array}{l}\text { White } \\
\text { Blue } \\
\text { Purple } \\
\text { Brown } \\
\text { Black }\end{array}$ & $\begin{array}{c}5 / 9 \% \\
14 / 24 \% \\
9 / 16 \% \\
13 / 23 \% \\
16 / 28 \%\end{array}$ & $\begin{array}{l}24 / 12 \% \\
54 / 28 \% \\
41 / 21 \% \\
32 / 17 \% \\
40 / 22 \%\end{array}$ & 0.16 \\
\hline Training floor & $\begin{array}{l}\text { Synthetic } \\
\text { Canvas }\end{array}$ & $\begin{array}{l}35 / 61 \% \\
22 / 39 \% \\
\end{array}$ & $\begin{array}{c}128 / 67 \% \\
63 / 33 \% \\
\end{array}$ & 0.16 \\
\hline Injury timing & $\begin{array}{c}\text { Training } \\
\text { Competition }\end{array}$ & $\begin{array}{l}49 / 86 \% \\
8 / 14 \%\end{array}$ & $\begin{array}{c}173 / 90 \% \\
18 / 10 \% \\
\end{array}$ & 0.15 \\
\hline $\begin{array}{l}\text { Fighter practices } \\
\text { another sport? }\end{array}$ & $\begin{array}{l}\text { Yes } \\
\text { No }\end{array}$ & $\begin{array}{l}40 / 70 \% \\
17 / 30 \% \\
\end{array}$ & $\begin{array}{l}133 / 70 \% \\
58 / 30 \% \\
\end{array}$ & 0.87 \\
\hline $\begin{array}{l}\text { JJB practice } \\
\text { time (years) }\end{array}$ & $\begin{array}{l}<2 \\
2-4 \\
\geq 4 \\
\end{array}$ & $\begin{array}{c}7 / 12 \% \\
11 / 19 \% \\
39 / 69 \% \\
\end{array}$ & $\begin{array}{l}23 / 12 \% \\
33 / 17 \% \\
135 / 71 \% \\
\end{array}$ & 0.87 \\
\hline $\begin{array}{c}\text { Number of training } \\
\text { sessions/week (days) }\end{array}$ & $\begin{array}{l}\leq 3 \\
>3\end{array}$ & $\begin{array}{l}16 / 28 \% \\
41 / 72 \% \\
\end{array}$ & \begin{tabular}{r|}
$63 / 33 \%$ \\
$128 / 67 \%$ \\
\end{tabular} & 0.32 \\
\hline BJJ Teacher & $\begin{array}{l}\text { Yes } \\
\text { No }\end{array}$ & $\begin{array}{l}13 / 23 \% \\
44 / 77 \%\end{array}$ & $\begin{array}{l}44 / 23 \% \\
147 / 77 \%\end{array}$ & 0.95 \\
\hline $\begin{array}{l}\text { Time off sport } \\
\text { (weeks) }\end{array}$ & $\begin{array}{l}\leq 1 \\
\leq 2 \\
\geq 4\end{array}$ & $\begin{array}{c}1 / 2 \% \\
9 / 16 \% \\
47 / 82 \% \\
\end{array}$ & $\begin{array}{c}38 / 20 \% \\
42 / 22 \% \\
111 / 58 \% \\
\end{array}$ & $<0.001$ \\
\hline Total & - & $57 / 100 \%$ & $191 / 100 \%$ & - \\
\hline
\end{tabular}


Regarding the main musculoskeletal injuries shown by fighters, $29.8 \%$ of them occurred in the knee joint $(p<0.001$ ) (Table 3 )

Table 3: Location of the four main sites of musculoskeletal injuries of JJB fighters.

\begin{tabular}{c|c|c|c}
\hline Injury Site & $\mathbf{n}$ & $\%$ & p-value \\
\hline Knee & 57 & $29.8 \%$ & Ref. \\
\hline Shoulder & 34 & $17.8 \%$ & 0.006 \\
\hline Ankle/Foot & 25 & $13.1 \%$ & $<0.001$ \\
\hline Wrist/hand & 18 & $9.4 \%$ & $<0.001$ \\
\hline
\end{tabular}

The main mechanism of knee injuries in BJJ fighters was the sprain (86\%) (Table 4). On the other hand, the most common ligament injury was the medial collateral ligament (MCL), with $38 \%$ of cases, followed by the lateral collateral ligament, with $19 \%$ of cases $(p=0.02)$ (Table 5). In $65 \%$ of the cases, the injuries were conservatively treated $(p<0.001)$ and, for the cases that required surgery, the most performed was simple knee arthroscopy (Figure 2).

Table 4. Mechanism of knee injuries in JJB fighters.

\begin{tabular}{c|c|c|c}
\multicolumn{6}{c}{ Table 4. Mechanism of knee injuries in JJB fighters. } & n/\% & p-value \\
\hline $\begin{array}{c}\text { Injury } \\
\text { mechanism }\end{array}$ & & $49 / 86 \%$ & Ref. \\
\hline Sprain & & $1 / 2 \%$ & $<0.001$ \\
\hline Bruise & & $2 / 3 \%$ & $<0.001$ \\
\hline Anterior & - Patellofemoral syndrome & $4 / 7 \%$ & \\
knee pain & - Patellar tendinopathy & $1 / 2 \%$ & $<0.001$ \\
\hline Fracture & & $57 / 100 \%$ & - \\
\hline Total & & &
\end{tabular}

Table 5. Types of injuries after knee sprain, in JJB fighters.

\begin{tabular}{c|c|c}
\hline Lesion & $\mathbf{n} / \%$ & $\mathbf{p}$-value \\
\hline $\mathrm{MCL}$ & $19 / 38 \%$ & Ref. \\
\hline Meniscal/Condral & $17 / 34 \%$ & 0.76 \\
\hline $\mathrm{LCL}$ & $9 / 19 \%$ & 0.02 \\
\hline $\mathrm{ACL}$ & $3 / 6 \%$ & $<0.001$ \\
\hline $\mathrm{PCL}$ & $1 / 3 \%$ & $<0.001$ \\
\hline Total & $49 / 100 \%$ & -
\end{tabular}

MCL: Medial collateral ligament; LCL: Lateral collateral ligament; ACL: Anterior cruciate ligament; PCL: Posterior cruciate ligament.

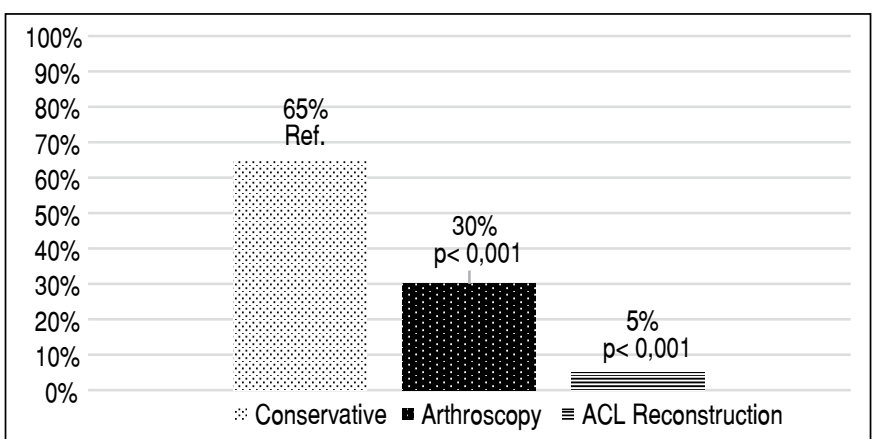

Figure 2. Treatment of injuries that occurred in the knee joint (in percentage).

\section{DISCUSSION}

This study showed a high proportion of knee injuries (29.8\%) in BJJ practitioners, compared to other sports. ${ }^{6-8,12,13}$ We emphasize the auxiliary nature of this measure for the elaboration of prevention protocols increasingly specific, based on the technical characteristics of the modality and the epidemiological nature of the injuries. The factors knowledge involved with the appearance of sports injuries, through epidemiological studies, is the first step towards understanding the complex interactions that involve this outcome in sport. ${ }^{9}$

This study indicates that the BJJ presented greater prevalence of injuries when compared with other martial arts and in other sports. Lystad et al., ${ }^{12}$ in a systematic review that assessed injuries in mixed martial arts (MMA), found an average proportion of $5.7 \%$ of knee injuries, over an average period of 3.5 years of evaluation. Akoto et al. $^{13}$ analyzed the injuries (which required more than a three-week leave) that occurred in 4,659 athletes practicing of judo, by an online questionnaire available for 90 days and found a frequency of $22.4 \%$ for the knee segment. Regarding other sports, which also involve rotational knee movements and great body contact, average proportions of $16 \%$ are observed in soccer, ${ }^{6}$ $12 \%$ in handball ${ }^{7}$ and $17 \%$ in basketball. ${ }^{8}$

Regarding BJJ, we identified varied data, mainly due to the different methodologies these studies. Moriarty et al., ${ }^{14}$ in a study with 1,287 adult athletes practicing Jiu-Jitsu, of both sexes, with a six-month follow-up, considered the concept of injury similar to that adopted in this study, in addition to not considering the skin as lesion topography. However, they considered injuries to the skull and face and analyzed a period of six months, with the finding of a $20.8 \%$ incidence of knee injuries.

McDonald's et $\mathrm{al} .{ }^{15}$ found a $9.2 \%$ proportion of knee injuries in a study with 140 Jiu-Jitsu practitioners of both sexes, over a 12-month period. However, this author was less comprehensive regarding the definition of injury and also considered injuries in regions of the skull, face and skin. If we considered only orthopedic injuries, this prevalence would be $10.8 \%$.

Machado et al. ${ }^{16}$ performed a study with 265 male competing athletes and evaluated the injuries that occurred in both training and in competition, with $28.4 \%$ of them on the knee. However, a very comprehensive criterion for the concept of injury was used, without even considering the need to withdraw from sport, which obviously causes an increase in this prevalence.

Scoggin et al., ${ }^{17}$ in a study that evaluated the incidence of injuries that occurred in world specialty championships (2,511 fights), all through medical diagnosis, over a period of seven years, observed a proportion of $19.4 \%$ of injuries in the knee (ranked second in the prevalence of injuries in this study).

The technical characteristics of the BJJ are represented by strokes that cause increased knee joint stress, both rotational and translational, and this is a major factor for the occurrence of injuries in this joint. These strokes are characterized mainly by blocking the joint in extension, through the articular keys, which cause high rotational torque according to the increase of the lever arm in the movement.

The leg lock is a submission maneuver in which the opponent suffers a high stress in knee hyperextension, which can predispose mainly to the occurrence of ligament injuries (anterior cruciate ligament and posterior cruciate ligament). On the other hand, when the fighter performs the arm lock attack, he gets high knee rotational stress. Another very common blow in the BJJ are the projections, which are also very likely to trigger knee injuries, either when the strike by the attacking fighter (lower support member) occurs or at the time of the defense attempt by the opposing athlete (at the moment of the fall, when performing ground support with the lower limb). All of these strokes are characterized mainly by the sprain injury mechanism, as was identified in this study and in others with similar methodologies. ${ }^{17,18}$ 
The projections are characterized by a predominance of stress in the valgus of the knee, with an increased chance of lesions of the MCL and medial meniscus. In this study, a predominance of injuries to the medial compartment of the knee (38\%) was detected. However, varus stresses are also prominent among knee injuries in the JJB. Scoggin et al. ${ }^{17}$ found a $57 \%$ prevalence of injuries to the lateral compartment, among the knee injuries observed in their study. Temponi et al., ${ }^{19}$ in a study that evaluated 27 athletes in the acute phase after knee sprain in the JJB practice, found a proportion of $25.9 \%$ with combined injuries of the lateral collateral ligament and anterolateral ligament complex.

In this study, most knee injuries occurred in isolated episodes and were of conservative treatment, however they demanded a high recovery time and return to sport (period equal to or greater than four weeks). Regarding of MCL injuries, which were the most common in this study, it is known that those originating from sports practice are characterized mainly by being of low or moderate degrees, conservative treatment and requiring an average recovery time of four weeks to six weeks, according to the rehabilitation protocol. ${ }^{20}$

In general, studies that address the occurrence of injuries in sports have different methodologies, such as regarding the concept of injury, the specific type, the analyzed period, among other factors that hinder the comparison between studies. In our study, we decided to use a questionnaire with a limit of three years, aiming to reduce the recall bias and, at the same time, not being a very short period of analysis. Moreover, the average time of BJJ practice of the athletes analyzed was 5.02 years, which is a factor favorable to the period of analysis that was stipulated in the study.

The cross-sectional design and the potential recall bias are the major limitations of the study. Besides, not all participants had their injuries diagnosed by a specialist doctor and/or by imaging exams. Another fact that deserves to be emphasized is the gender bias, which occurs in practically all studies with martial arts, which are practiced by a great predominance of male athletes.

\section{CONCLUSION}

The proportion of knee injuries observed in this study was higher than that of other sports that perform movements similar to those of the JJB. This knowledge is important in the elaboration of injury prevention and training prescription protocols that are increasingly specific to the sport, as already adopted in other sports, such as football.

AUTHORS' CONTRIBUTIONS: Each author contributed individually and significantly to the development of this article. JMJE: writing, drafting the database, carrying out the statistical analysis, reviewing and approving the final version of the manuscript; ALR: sending the questionnaires and preparing the database PD: writing the work and reviewing the intellectual content; CCK: essay writing and review of intellectual content; OBN: review and approval of the final version of the manuscript. All authors reviewed and approved the final version of the manuscript.

\section{REFERENCES}

1. Gracie R, Gracie C, Peligro K, Danaher J, editor. Brazilian jiu-jitsu: theory and technique. Montpelier: Invisible Cities Press; 2000.

2. Villar R, Gillis J, Santana G, Pinheiro DS, Almeida AL. Association between anaerobic metabolic demands during simulated Brazilian Jiu-Jitsu combat and specific Jiu-Jitsu anaerobic performance test. J Strength Cond Res. 2018;32:432-40.

3. Andreato LV, Lara FJD, Andrade A, Branco BHM. Physical and physiological profiles of Brazilian jiu-jitsu athletes: a systematic review. Sports Med Open. 2017;3(9):1-17

4. Sousa DF, Eustaquio JMJ, Marocolo M, Mota GR, Barbosa Neto O. Alterações autonômicas cardíacas em diferentes perfis táticos do Jiu Jitsu Brasileiro. Rev Bras Med Esporte. 2020;26(3):196-200.

5. Lima PO, Lima AA, Coelho AC, Lima YL, Almeida GPL, Bezerra MA, et al. Biomechanical differences in Brazilian Jiu-Jitsu athletes: the role of combat style. Int J Sports Phys Ther. 2017;12(1):67-74.

6. Roos KG, Wasserman EB, Dalton SL. Epidemiology of 3825 injuries sustained in six seasons of National Collegiate Athletic Association men's and women's soccer (2009/2010-2014/2015). Br J Sports Med. 2017;51:1029-34.

7. Bere T, Alonso JM, Wangensteen A, Bakken A, Eirale C, Dijkstra P, et al. Injury and illness surveillance during the 24th men's Handball World Championship 2015 in Qatar. Br J Sports Med. 2015;49:1151-6.

8. Andreoli CV, Chiaramonti BC, Buriel E, Pochini AC, Ejnisman B, Cohen M. Epidemiology of sports injuries in basketball: integrative systematic review. BMJ Open Sport Exerc Med. 2018;4(1):e000468.

9. Bittencourt NFN, Meeuwisse WH, Mendonça LD, Nettel-Aguirre A, Ocarino JM, Fonseca ST. Complex systems approach for sports injuries: moving from risk factor identification to injury pattern recognition - narrative review and new concept. Br J Sports Med. 2016;50(21):1309-14.

10. Pastre CM, Carvalho Filho G, Monteiro HL, Netto J Jr, Padovani CR. Lesões desportivas no atletismo: comparação entre informações obtidas em prontuários e inquéritos de morbidade referida. Rev Bras Med Esporte. 2004;10:1-8.
11. Weisenthal BM, Beck CA, Maloney MD, Dehaven KE, Giordano BD. Injury rate and patterns among CrossFit athletes. Orthop J Sports Med 2014;2(4):2325967114531177.

12. Lystad RP, Gregory K, Wilson J. The epidemiology of injuries in mixed martial arts: a systematic review and meta-analysis. Orthop J Sports Med 2014;2(1):2325967113518492.

13. Akoto R, Lambert C, Balke M, Bouillon B, Frosch KH, Hoher J. Epidemiology of injuries in judo: a cross-sectional survey of severe injuries based on time loss and reduction in sporting level. Br J Sports Med. 2018;52(17):1109-15.

14. Moriarty $\mathrm{C}$, Charnoff J, Felix ER. Injury rate and pattern among Brazilian jiu-jitsu practitioners: a survey study. Phys Ther Sport. 2019;39:107-13.

15. McDonald AR, Murdock FA, McDonald JA, Wolf CJ. Prevalence of injuries during BJJ training. Sports. 2017;5(2):39-47.

16. Machado AP, Machado GP, De Marchi T. A prevalência de lesões no Jiu-Jitsu de acordo com relatos dos atletas participantes dos campeonatos mundiais em 2006. Cons Saude. 2012;11(1):85-93.

17. Scoggin JF, Brusovanik G, Izuka BH, van Rilland EZ, Geling O, Tokumura S Assessment of injuries during Brazilian jiu-jitsu competition. Orthop J Sports Med. 2014;2(2):2325967114522184.

18. Stephenson C, Rossheim ME. Brazilian jiu jitsu, judo, and mixed martial arts injuries presenting to United States emergency departments, 2008-2015. J Prim Prev. 2018;39(5):421-35.

19. Temponi EF, Saithna A, Carvalho LH, Teixeira BP, Sonnery-Cottet B. Nonoperative treatment for partial ruptures of the lateral collateral ligament occurring in combination with complete ruptures of the anterolateral ligament: a common injury pattern in Brazilian jiu-jitsu athletes with acute knee injury. Orthop J Sports Med. 2019;7(1):2325967118822450.

20. Lundblad M, Hägglund M, Thomeé C, Senorski EH, Ekstrand J, Karlsson J, et al. Medial collateral ligament injuries of the knee in male professional football players: a prospective three-season study of 130 cases from the UEFA Elite Club Injury Study. Knee Surg Sports Traumatol Arthrosc. 2019;27(11):3692-8 